\title{
LANSKAP SPIRITUAL SITUS LIYANGAN
}

\section{SPIRITUAL LANDSCAPE OF LIYANGAN SITE}

\author{
Daud Aris Tanudirjo ${ }^{*}$, J.S.E. Yuwono2 ${ }^{2}$, Ari Mukti Wardoyo Adi ${ }^{3}$ \\ Fakultas Ilmu Budaya, Universitas Gadjah Mada, Indonesia ${ }^{1,2}$ \\ Fakultas Ilmu Budaya, Universitas Jambi, Indonesia ${ }^{3}$ \\ daud.tanudirjo@ugm.ac.id
}

\begin{abstract}
Liyangan archaeological site in the village of Purbasari, Residency Temanggung, Central Java, is an Old Mataram settlement predictably existed from around 8th to 10th century CE. In this site, which was buried by thick layers of pyroclastic materials of Gunung Sindoro eruption, various artefacts as well as stone structures are found including pavement, altars, retaining walls, water-temple, and remains of wooden structures. One of the most interesting aspect of this site is the orientation of the stone structures. Although the whole settlement was arranged to follow the sloping contour of the Mount Sindoro, most of the stone structures were oriented to southeast, which was not common for stone shrines built at the same period. This paper attempts to explain the reason for such an exceptional orientation using landscape archaeological approach. Our research demonstrates that the ten Liyangan stone structures were oriented to either Mount Merapi, Baka Hill, or the Prambanan temple. The orientation of the stone structures is believed as a reflection of the spatial map and the cosmology of the community lived in Liyangan centuries ago. It is suggested here that such an orientation represents the so-called "spiritual landscape" of the people.
\end{abstract}

Keywords: Situs Liyangan ; landscape archaeology; spiritual landscape; Mount Sindoro; Mount Merapi; Mataram Hindu kingdom

\section{ABSTRAK}

Situs Liyangan di Desa Purbasari, Temanggung, Jawa Tengah, adalah situs permukiman masa Kerajaan Mataram Kuno, yang diperkirakan berasal dari sekitar abad ke-8 hingga ke-10. Di situs ini yang tertimbun awan panas erupsi Gunungapi Sindoro, ditemukan beragam artefak dan sejumlah struktur maupun bangunan antara lain berupa batur, altar pemujaan, talud batu, petirtaan dan sisa bangunan kayu terbakar. Salah satu aspek yang menarik adalah orientasi permukiman tersebut. Secara umum tata bangunan disusun mengikuti kontur tanah yang semakin tinggi menuju puncak Gunung Sindoro. Namun, arah hadap bangunan yang ada justru ke tenggara. Tulisan ini mencoba untuk memberikan penjelasan kemungkinan alasan yang ada di balik fenomena tersebut melalui pendekatan arkeologi lanskap. Hasil penelitian menunjukkan orientasi sepuluh bangunan yang diambil sebagai sampel mengarah ke Gunung Merapi, Bukit Baka, dan Candi Prambanan. Orientasi bangunan merupakan salah satu wujud dari kosmologi dan peta keruangan komunitasnya. Dalam kasus Situs Liyangan, orientasi itu menggambarkan lanskap spiritual yang dimiliki oleh pendiri situs ini.

Kata Kunci: Situs Liyangan ; arkeologi lanskap; lanskap spiritual; Gunung Sindoro; Gunung Merapi; kerajaan Mataram Hindu
Artikel Masuk
: 16-09-2019
Artikel Diterima

$$
\text { : 01-11-2019 }
$$




\section{PENDAHULUAN}

Situs Liyangan berada di lereng timur laut Gunungapi Sindoro, tepatnya di Dusun Liyangan, Desa Purbasari, Kecamatan Ngadirejo, Kabupaten Temanggung, Jawa Tengah. Secara astronomis situs ini berada pada koordinat $7^{\circ}$ $15^{\prime}$ 6,7766" LS - $110^{\circ} 01^{\prime} 37,2203^{\prime \prime}$ BT dan pada ketinggian antara 1.100 - 1.200 meter dari permukaan air laut. Situs permukiman bercorak Hinduistik ini ditemukan terkubur di bawah lapisan endapan aliran piroklastik atau awan panas setebal 4 7 meter. Situs Liyangan menjadi kapsul waktu yang dapat memberikan informasi cukup lengkap tentang permukiman Jawa Kuno. Temuan arkeologi seperti itu sangat jarang terjadi. Hingga penelitian ini dilakukan area situs yang sudah terungkap sekitar $200 \mathrm{~m} \times 300 \mathrm{~m}$ atau 6 hektar dan sejumlah temuan baru masih terus dilaporkan. Diyakini, saat ini area Situs Liyangan yang terkupas sudah jauh lebih luas karena aktivitas pertambangan yang terus berlangsung meskipun telah dilarang.

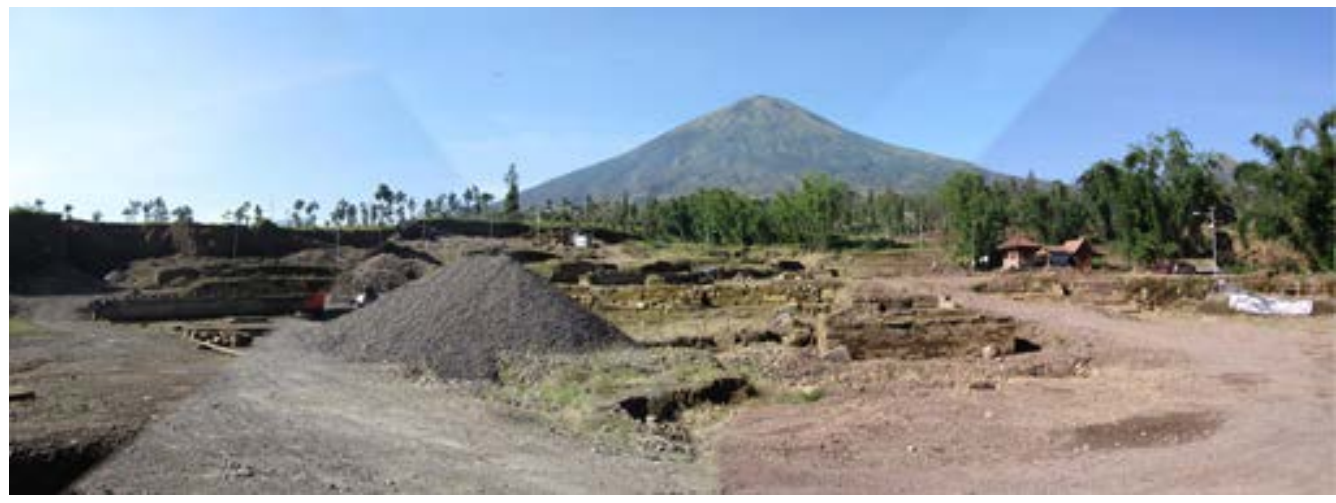

Gambar 1. Kondisi Situs Liyangan saat dilakukan penelitian pada tahun 2015 (Sumber: Daud Aris Tanudirjo)

Keberadaan Situs Liyangan sesungguhnya sudah mulai terkuak sejak tahun 2000, ketika seorang penduduk Dusun Liyangan melaporkan temuan struktur balok-balok batu yang membentuk dinding teras atau talud tebing. Struktur batu itu ditemukan saat menggali tanah untuk fondasi rumah di lingkungan permukiman dusun itu. Namun, selama beberapa tahun temuan ini tidak cukup mendapat perhatian. Pada tahun 2008, para penambang batu dan pasir di Dusun Liyangan melaporkan lagi temuan lain berupa batur dan pagar dari batu, kayu-kayu yang terbakar, biji padi terkarbonasi, dan juga beberapa alat dari logam maupun keramik asing. Sejak itu, perhatian lebih besar diberikan pada situs itu. Hampir setiap tahun tim arkeologi Balai Arkeologi Yogyakarta maupun Balai Pelestarian Cagar Budaya Jawa Tengah melakukan penelitian dan upaya penyelamatan, sementara pada saat yang sama proses pertambangan batu dan pasir terus berlangsung dalam skala intensitas yang tinggi (Balai Arkeologi Yogyakarta, 2012; 2013; 2014).

Serangkaian penelitian arkeologi dan kegiatan penambangan yang telah dilakukan di situs tersebut selama beberapa tahun telah berhasil mengungkapkan temuan-temuan menarik, di antaranya struktur talud, struktur jalan dari tatanan batu alam, sisa bangunan kayu beratap ijuk yang terbakar, pagar batu, batur-batur candi dari batu, altar batu di atas batur, bahkan juga bangunan petirtaan. Sejumlah 
artefak lepas yang ditemukan terdiri dari keramik asing, alat-alat dan senjata dari logam, perhiasan, arca, yoni, dan batu berukir berbentuk setengah lingkaran. Selain itu, di beberapa tempat ditemukan juga sisa-sisa tanaman yang pada umumnya sudah terkarbonasi karena hangus, di antaranya padi dan jagung (Andrianto, 2014). Selain itu, ditemukan juga lapisan tanah yang terbentuk dari hamparan timbunan kulit padi terkarbonasi (hasil pengamatan pada Januari 2015).

Dari data yang sejauh ini sudah terkumpul, sejumlah penafsiran telah dikemukakan oleh para peneliti. Situs Liyangan ditafsirkan sebagai permukiman kuno dari Masa Klasik Jawa Tengah, sekitar abad ke-7 hingga ke-10, dengan ciri temuan bersifat Hinduistik. Permukiman ini terlanda awan panas erupsi Gunungapi Sindoro, yang menghasilkan endapan material dengan ketebalan hingga 7 meter dan setidaknya terdiri atas empat lapisan atau sekuen (Putra, dkk., 2013, hlm. 48-52). Jarak waktu pengendapan antara setiap sekuen tidak jauh berbeda. Namun, kapan erupsi ini terjadi belum diketahui secara pasti. Beberapa pertanggalan yang ada masih belum dapat memberikan kepastian, karena data yang berbeda-beda. Erupsi Gunungapi Sindoro sendiri terjadi berkali-kali, sejak sekitar 34.000 tahun lalu setidaknya terjadi sebanyak 12 erupsi. Beberapa pertanggalan absolut yang dihasilkan dari sejumlah penelitian menunjukkan adanya serangkaian erupsi setelah memasuki Tarikh Masehi, mulai dari sekitar $230 \mathrm{M}$ hingga abad ke-19, dan catatan terakhir menunjukkan erupsi terjadi pada tahun 1970-1971 (Sukyar, dkk., 1992; Riyanto, 2014b, hlm. 101; Prambada, dkk., 2016, hlm. 81).

Keberadaan Situs Liyangan yang hancur karena aliran piroklastik Gunungapi Sindoro seringkali dikaitkan pula dengan isi Prasasti Rukam yang ditemukan di Desa Petarongan, Kecamatan Parakan, tidak jauh dari Situs Liyangan. Dalam prasasti yang diterbitkan oleh Sri Maharaja Rake Watukura Dyah Balitung dan berangka tahun $907 \mathrm{M}$ itu, memang disebutkan adanya desa yang hilang karena letusan gunung (Resiyani, 2010; Nastiti, 1982, hlm. 23-36). Namun, tafsiran terhadap kemungkinan Situs Liyangan adalah desa atau wanua Rukam yang hilang karena letusan gunung masih diragukan. Diduga kuat wanua Rukam bukanlah desa yang hancur, tetapi justru desa yang menggantikan desa yang hancur (Mochtar, 2014, hlm. 155). Risalah sejumlah erupsi Gunungapi Sindoro terbaru dihasil oleh Prambada dkk (2016) berdasarkan pertanggalan absolut yang cukup meyakinkan. Dalam risalah itu setidaknya ada dua erupsi yang hampir sejaman dengan prasasti Rukam. Keduanya hanya terpaut beberapa abad, yaitu sekitar abad ke-8 dan abad ke-1). Informasi baru ini membuat diskusi tentang identifikasi wanua Rukam dengan Situs Liyangan akan semakin terbuka dan menarik. Pengamatan tim peneliti terhadap temuan sejumlah struktur batu yang telah ditemukan memang memberikan kesan adanya dua tahap pembuatan struktur-struktur batu tersebut (lihat penjelasan di bawah).

Perbincangan tentang proses penghunian dan bencana yang melanda permukiman kuno Liyangan mungkin masih akan berlanjut dan sejumlah data baru akan terus terkuak. Namun, masalah tersebut bukanlah fokus perhatian penelitian yang akan dibahas dalam tulisan ini. Penelitian yang mendasari tulisan ini justru lebih tertuju pada keberadaan dan arah kiblat (orientasi) sejumlah struktur batu yang telah terungkap di Situs Liyangan yang belum mendapat cukup perhatian dari peneliti lain. Pengamatan kami terhadap setidaknya sepuluh 
struktur batu, baik berupa batur, kaki candi, maupun petirtaan menunjukkan arah hadap yang tidak lazim bagi bangunan pemujaan (candi) pada masa itu, yang biasanya diarahkan ke mata arah mata angin utama Barat - Timur. Orientasi lain yang umum dipakai adalah arah gunung - laut atau kaja - kelod di Bali (lihat Soekmono, 1977; Atmadi, 1997, hlm. 125-129; DeGroot, 2009, hlm. 106). Tentu saja, ketidaklaziman ini mengundang pertanyaan terkait latar pemikiran atau konsep yang ada di balik orientasi struktur atau "candi-candi" di Situs Liyangan tersebut.

\section{METODE}

Kajian arkeologi terhadap dampak bencana gunungapi dapat mengungkapkan banyak data yang tidak jarang cukup mengejutkan. Banyak contoh menunjukkan hal itu. Kajian yang dilakukan Sheet (2007) di situs permukiman kuno Zapotitan El Salvador, misalnya, mengungkapkan ketahanan masyarakat masa lalu terhadap bencana gunungapi. Meskipun mereka terpaksa harus mengungsi, mereka tidak ingin meninggalkan tempat hunian semula, sehingga selalu kembali lagi ke permukiman semula. Fenomena yang juga sangat sering terjadi dalam konteks budaya Jawa maupun Indonesia pada umumnya. Kajian lain (Grattan dan Torrence, 2007) juga meyakinkan bahwa ternyata lapisan tanah yang mengubur suatu situs seringkali justru menyediakan sejumlah pertanggalan yang cukup runtut, sehingga rekonstruksi bencana dan permukiman yang terdampak dapat dilakukan dengan baik. Karena itu, situs yang terkubur endapan erupsi gunungapi seperti Situs Liyangan berpotensi menyediakan data yang cukup baik untuk mengungkapkan banyak hal tentang budaya komunitas yang pernah menempati situs itu. Salah satu aspek yang menarik dari sistem pengetahuan yang masih dapat terekam pada situs seperti itu adalah tentang ruang atau kosmologi yang mereka pahami. Hal ini dimungkinkan karena endapan erupsi gunungapi tidak menghancurkan segalanya, tetapi seringkali justru menyisakan jejak-jejak penataan ruang yang masih berada pada tempatnya semula. Kajian keruangan, kosmologi, maupun imaji tentang lingkungan masa lampau dalam konteks perkembangan arkeologi kini lebih banyak tertampung dalam kajian arkeologi lanskap (landscape archaeology).

Dalam sejarah perkembangan arkeologi, kajian topik lanskap sesungguhnya bukan merupakan hal yang baru. Aspek hubungan antara pemahaman manusia tentang ruang di sekitar dan cara mereka menempatkan diri pada lingkungan itu sudah menjadi kajian yang cukup banyak dilakukan bahkan sejak awal perkembangan ilmu ini. Salah satu perintis arkeologi, Pitt River pada akhir abad ke-19 sudah menaruh perhatian besar tentang hal ini. Namun, kajian ini semakin mendapat perhatian dari para ahli arkeologi pada dua dasawarsa terakhir ini (Thomas, 2001), terutama dengan perubahan pandangan tentang arkeologi dan cara-cara dalam menafsirkan data berupa bentang alam (nature) dan budaya (culture) yang tidak lagi dilihat secara terpisah. Sebaliknya, kini bentang alam dan budaya seakan tidak dapat dilihat secara berbeda. Kini pemahaman tentang lanskap atau saujana menjadi begitu beragam dan dapat dikaitkan hampir dengan apa saja: benda, bentang alam, tata ruang, pengalaman, pandangan atau persepsi, maupun konstelasi hubungan antar bagian dalam suatu aspek kehidupan (misalnya, economic landscape, political landscape). Lanskap tidak lagi dilihat sebagai entitas fisik, tetapi juga cakrawala pemikiran atau sering disebut 
sebagai "landscape of mind". Dalam konteks lanskap pemikiran ini, kosmologi atau pengetahuan tentang "jagad" menjadi aspek yang penting dalam membentuk cakrawala pikir itu (Layton dan Ucko, 1999; Thomas, 2001; Tacon, 2011).

Cara pandang itu antara lain telah menghasilkan istilah associative landscape yang menjadi salah satu jenis lanskap budaya dalam konteks jenis-jenis warisan budaya dunia. Associative landscape dimaknai sebagai warisan budaya yang hanya dapat dipahami jika dikaitkan dengan konsep kepercayaan, pengetahuan, atau seni tertentu (UNESCO, 2012). Lanskap diyakini sebagai perwujudan nyata akan pemahaman komunitas tentang dunianya atau "a way to seeing the world." Olehkarena itu, lanskap biasanya juga akan merujuk pada entitas fisik tertentu, sehingga lanskap adalah paduan antara alam dan budaya. Karena pemahaman itu, kajian tentang lanskap kini lebih dipahamai sebagai bentuk kajian tentang kesadaran manusia atau persepsi mereka tentang ruang (Layton dan Ucko, 1991; Thomas, 2001).

Sesuai dengan pemahaman tentang lanskap tersebut, maka rekonstruksi lanskap yang dilakukan di Situs Liyangan tidak hanya akan terbatas pada tatanan ruang fisik saja, tetapi lebih daripada itu akan diarahkan untuk mengungkapkan konsepsi dan persepsi penghuni situs itu terhadap "dunia" atau "lingkungan" di sekitarnya. Dalam tradisi arkeologi, upaya untuk menemukan "pikiran manusia" mengenai "dunia"-nya itu biasanya dilakukan dengan melihat keberadaan monumen-monumen. Karena, pada hakekatnya, monumen tidak lain adalah ekspresi pikiran manusia tentang dunia. Monumen yang erat berhubungan dengan ritual bagi cikal-bakal (ancestry) berperan penting dalam komunitas sebagai sarana menjaga kestabilan sosial dan melanggengkan tradisi. Lebih daripada itu, struktur dan keletakan bangunan sakral biasa dianggap sebagai representasi atau bentuk kecil (microsomos) dari lanskap alam raya (Thomas, 2001).

Dalam kajian lanskap, setidaknya ada tiga konsep lanskap yang masingmasing dipahami sesuai dengan ranah kajian keilmuannya. Bagi mereka yang berkecimpung dalam ranah sains, umumnya lanskap dilihat sebagai lingkungan fisik yang menjadi latar bagi kegiatan manusia, seperti gunung, bukit, lembah, sungai, danau, atau laut. Artinya, lanskap cenderung dilihat sebagai bagian dari alam fisik (nature). Dalam ranah ilmu sosial, lanskap lebih dipahami sebagai cara pandang atau kondisi yang dipahami. Konsep ini dikaitkan dengan fenomena lukisan "lanskap" dalam seni lukis, yang merupakan hasil "persepsi manusia" terhadap bentang lingkungan tertentu. Di sini, unsur "persepsi manusia" itu akan menghasilkan gambaran yang bersifat "subyektif dan representatif" tentang keseluruhan lingkungan yang sesungguhnya ada dan dilihat oleh manusia. Karena kuatnya faktor "manusia" maka lanskap lebih dipahami sebagai budaya (culture). Namun, kini semakin dipahami bahwa lanskap itu bukan entitas "alami" atau pun "budayawi", tetapi satu kondisi yang dihasilkan oleh "proses sejarah" hubungan antara manusia dan alam yang saling mempengaruhi. Pemahaman ketiga ini kemudian menempatkan unsur utama lanskap pada kegiatan manusia (Allterton, 2009; baca juga Schulke, 2016; Knaap dan Ashmore, 1999; Thomas, 2001).

Apabila lanskap dilihat sebagai proses interaksi manusia dan lingkungannya, maka lanskap itu tentu mendasari tidak saja kegiatan keseharian yang bersifat profan, tetapi juga mewujud dalam aktivitas maupun pemikiran religius atau menunjukkan hubungan manusia dengan "Yang Adikodrati" 
(supernatural). Dengan merujuk pada cara pikir ini, Allterton (2009, hlm. 4) lalu menyarankan penggunaan "spiritual landscape" (lanskap spiritual) untuk menggambarkan cara-cara manusia membayangkan adanya kekuatan spiritual atau energi-energi yang menempati atau keluar dari tempat-tempat tertentu. Bayangan akan adanya kekuatan-kekuatan yang ada di luar diri manusia itu, dirasakan tetapi tak tampak, tentu akan membawa sikap tertentu untuk berhubungan maupun menghadapinya. Konsep Allterton tentang "lanskap spiritual" ini sesungguhnya hampir sama dengan apa yang disebutkan oleh Tuan (1977, hlm. 85 - 88) sebagai " mythical space" atau ruang mitis, yang terbentuk ketika manusia membayangkan ruang-ruang yang tidak begitu diketahuinya atau yang tidak dialaminya secara empiris. Ruang mitis ini memberikan kesempatan bagi manusia untuk dapat menciptakan gambaran "dunia" di luar diri sesuai dengan pikiran yang dimilikinya.

Gambaran tentang "dunia" di luar jangkauan pengalaman empirisnya diperlukan untuk menjadikan lingkungannya dapat dipahami atau "masuk akal", sehingga manusia akan mampu menempatkan dirinya dan berperilaku harmonis dengannya. Perilaku yang kurang sesuai dengan apa yang dibayangkan dianggap akan dapat menganggu kekuatan alam (roh-roh) maupun para dewa yang dibayangkan ada di "dunia" tersebut. Jadi, pandangan tentang dunia, atau kosmologi, atau "lanskap" dibutuhkan agar manusia dapat hidup dengan tata cara yang benar dalam dunia (Tuan, 1977, hlm. 88). Lebih lanjut, pada umumnya ruang mitis yang digambarkan oleh manusia itu akan diwujudkan menjadi tempat-tempat tertentu yang akhirnya akan menjadi kiblat tertentu bagi manusia. Pada tahap itulah "ruang" (space) menjadi "tempat" (place), suatu entitas yang lebih nyata dan mudah diinderakan. Dengan cara itu, sesungguhnya manusia berupaya mengorganisasikan kekuatan-kekuatan alam di luar dirinya itu (Tuan, 1977, hlm. 91).

Kerangka pikir yang dijelaskan di atas akan digunakan dalam penelitian ini. Karena itu, keberadaan struktur serta tata ruang dan tata bangunan di Situs Liyangan menjadi amat penting dalam kajian ini. Meskipun demikian, perlu dicatat pula bahwa sejumlah data yang ada di Situs Liyangan lebih banyak ditemukan sebagai akibat kegiatan penambangan dan bukan kegiatan ekskavasi arkeologis. Keadaan ini sedikit banyak akan menjadi kendala dan sekaligus tantangan untuk dapat mencapai hasil rekonstruksi lanskap yang maksimal. Mengingat kondisi yang ada, penelitian ini akan lebih dipusatkan pada data struktur atau bangunan yang relatif tidak terganggu keasliannya letak maupun orientasinya. Hal ini dipastikan dengan mengamati secara cermat keadaan batuan penyusun struktur yang dapat diyakini tidak bergeser dari tatanan aslinya. Selain itu, penelusuran terhadap informasi dan catatan penanganan temuan struktur dilakukan untuk memastikan belum ada upaya rekonstruksi struktur yang dipilih sebagai sampel penelitian pasca-penemuannya.

Metode yang digunakan cukup sederhana yaitu mengukur derajat orientasi (bearing) struktur atau bangunan yang menjadi sampel. Setidaknya ada sepuluh sampel struktur yang akan diukur orientasinya. Kesepuluh struktur tersebut adalah pertirtaan di teras pertama (paling bawah), batur atau kaki candi di teras kedua (Candi I) dan dua batur di teras ketiga (Batur 1 dan 4), serta enam batur yang ada di teras keempat. Pengukuran orientasi dilakukan dalam empat tahap. Tahap pertama adalah pemetaan terestrial masing-masing bangunan dan 
struktur secara detail dengan alat total station. Titik referensi menggunakan patok yang digunakan dalam penelitian oleh Balai Arkeologi DIY. Dalam tahap ini juga dilakukan pengkoreksian koordinat beberapa titik referensi menggunakan GPS geodetik Leica Viva GS08 yang kemudian datanya langsung diinput ke dalam total station. Tahap kedua adalah memindahkan data titik hasil survei terestrial ke dalam software ArcGIS. Pada tahap ini, dilakukan pemilahan titik berdasarkan identitas (ID) jenis yang telah ditetapkan, yakni bangunan, struktur, titik referensi dan topografi. Titik yang digunakan selanjutnya adalah yang memiliki ID bangunan dan struktur, karena titik ini merupakan representasi dari sisi-sisi terluar struktur dan bangunan, antara lain sisa ambang pintu dan bidang samping batur. Tahap ketiga adalah merubah titik dengan ID bangunan dan struktur menjadi data polygon. Pengukuran orientasi dilakukan terhadap data polygon yang dibuat dari titik tersebut menggunakan sistem sudut kutub (polar angle system) dengan satuan derajat. Pada tahap keempat, dilakukan penarikan garis perpanjangan (extend) orientasi bangunan sehingga ditemukan persinggungan garis perpanjangan tersebut dengan objek-objek yang diduga sebagai kiblat atau orientasi bangunan dan struktur di Situs Liyangan.

\section{HASIL PENELITIAN}

Dari serangkaian penelitian arkeologi yang telah dilakukan, khususnya sejak tahun 2008 hingga Agustus 2015, sejumlah hasil temuan arkeologis telah berhasil diungkap di Situs Liyangan . Berdasarkan Laporan Penelitian Arkeologi tahun 2012, 2013, dan 2014 yang disusun tim penelitian Balai Arkeologi Yogyakarta, ada cukup banyak ragam jenis temuan artefaktual dan nonartefaktual yang berhasil digali dari situs ini. Di beberapa lokasi, baik di atas talud maupun di teras halaman, terdapat sisa-sisa kayu, bambu dan ijuk terbakar yang merupakan sisa-sisa bangunan. Sisa-sisa biji-biji tanaman, termasuk padi dan jagung (?), dilaporkan ditemukan pula, selain tentunya kayu batang pohon yang terbakar. Beberapa sampel arang yang dianalisis secara radiometrik C-14 menunjukkan pertanggalan 587, 742, 846, 913, dan 971 Masehi [sic] (Riyanto, 2014b, hlm. 100).

Sementara itu, jenis artefak yang ditemukan antara lain berupa wadah maupun pecahan keramik asing (Cina) dari Dinasti Tang maupun Lima Dinasti, gerabah, kaca, alat logam, pipisan batu (pestle and mortar), yoni dan arca berciri Hinduisme, juga ditemukan. Analisis keramik asing memberikan perkiraan pertanggalan relatif yang menempatkan situs ini pada abad ke-9 (Eriawati, 2014, hlm. 261).

Salah satu temuan menarik lainnya adalah rangka manusia yang mengindikasikan penguburan sekunder. Rangka ini diidentifikasikan berciri rasial Mongoloid dengan sedikit unsur Austromelanesoid. Walaupun pertanggalan C-14 menunjukkan angka $2231 \pm 25 \mathrm{BP}$, pertanggalan tersebut lebih merujuk pada umur tanah di sekitar temuan rangka daripada rangka manusianya sendiri (Noerwidi, 2014, hlm. 316-317).

\section{Temuan Struktural di Situs Liyangan}

Sesuai dengan fokus penelitian ini, temuan berupa struktur-struktur batu menjadi perhatian utama dalam tulisan ini. Adanya sejumlah struktur yang 
ditemukan dalam kondisi yang cukup baik dan masih berada di tempatnya membuka peluang yang cukup besar untuk dapat menemukan "lanskap" yang dipersepsikan oleh penghuni Situs Liyangan. Berikut ini akan dideskripsikan keadaan struktur dan keletakannya.

Salah satu jenis temuan struktural yang cukup menonjol di Situs Liyangan adalah talud, yaitu susunan batu yang difungsikan sebagai perkuatan dinding tebing. Pengamatan Tim Peneliti mendapatkan talud-talud di situs ini dapat dibedakan menjadi dua berdasarkan orientasinya. Kelompok pertama adalah talud-talud yang membentang arah tenggara - barat laut. Talud-talud ini rupanya lebih berfungsi sebagai pembatas halaman situs yang membentuk teras-teras berundak semakin tinggi mengikuti kontur lereng gunung mengarah ke puncak Gunung Sindoro di arah barat daya. Berdasarkan temuan yang teramati kini, setidaknya terdapat tujuh teras di area situs ini, tidak termasuk temuan tahun 2000 di tengah permukiman dusun Liyangan.

Sementara itu, kelompok talud yang lain disusun dengan arah barat daya - timur laut. Talud-talud ini hanya terdapat di sisi tenggara situs dan belum ditemukan pada sisi barat daya. Tampaknya fungsi talud sebagai penyangga tanah yang lebih tinggi di sektor tenggara ini. Karena orientasinya searah dengan lereng gunung, maka talud ini dibangun mengikuti kelerengan gunung, semakin rendah ke arah timur laut. Pada saat pengamatan dilakukan (2015) telah ditemukan 4 (empat) jalur talud. Talud yang paling rendah sebagian disusun dari batu-batu bulat dan sebagian penggal lain disusun dari batu yang dibentuk persegi panjang. Talud kedua disusun dari batu bulat, sejajar dan berada sekitar 4 meter jaraknya dari talud pertama. Ketinggian talud kedua ini lebih tinggi antara 1,5 - $2 \mathrm{~m}$ dari talud pertama. Sebagian talud ini belum terungkap. Talud ketiga juga dibuat dari batu bulat yang disusun sejajar dengan dua talud lainnya, dengan jarak sekitar 6 m dari talud kedua, serta lebih tinggi sekitar $2-3 \mathrm{~m}$. Jalur talud yang lain, baru ditemukan akibat aktivitas penambangan pada Juli - Agustus 2015, berada di tenggara talud ketiga, memanjang sekitar tujuh meter dan tersusun dari batu bulat. Di ujung bagian barat daya, talud ini membentuk sudut siku dengan talud lain yang mengarah barat laut - tenggara.

Selain talud, jalan batu sepanjang kurang lebih $150 \mathrm{~m}$ juga berhasil ditampakkan. Jalan batu ini membentang dari teras paling bawah hingga teras kelima. Jalan ini tepat berada di barat daya talud pertama dan arahnya sejajar pula, sehingga talud pertama seakan menjadi dinding tenggara jalan batu. Pada teras kelima, jalan batu berakhir pada lima tingkat "anak tangga" yang disusun dari bungkah-bungkah besar batu berbentuk tidak teratur tetapi umumnya dipilih dari batu-batu yang bentuknya cenderung pipih.

Sepanjang sisi barat laut jalan batu, terdapat pagar batu yang tersusun dari balok batu persegi dan di beberapa bagian atas pagar masih terdapat sejumlah kemuncak pagar. Pagar ini menjadi pembatas antara halaman teras ketiga dan keempat dengan jalan batu di tenggaranya. Dengan demikian, jalan batu diapit oleh dinding talud (di tenggara) dan pagar batu (di barat laut).

Selanjutnya akan diuraikan secara lebih rinci temuan struktural yang terdapat pada tujuh halaman teras yang telah berhasil ditampakkan di Situs Liyangan. Uraian ini terutama didasarkan pada hasil pengamatan yang dilakukan pada tahun 2015. 
Di teras paling bawah (sementara ini) terdapat petirtaan yang belum seluruhnya terungkap (Gambar 2.). Petirtaan ini berada di bawah permukaan tanah situs pada umumnya dan berada di sisi barat laut jalan batu. Terdapat setidaknya tiga atau empat talud untuk memperkuat dinding tebing di atas petirtaan. Hasil ekskavasi di halaman atas petirtaan menunjukkan adanya sejumlah fitur yang diduga bekas tiang penyangga bangunan (postholes).

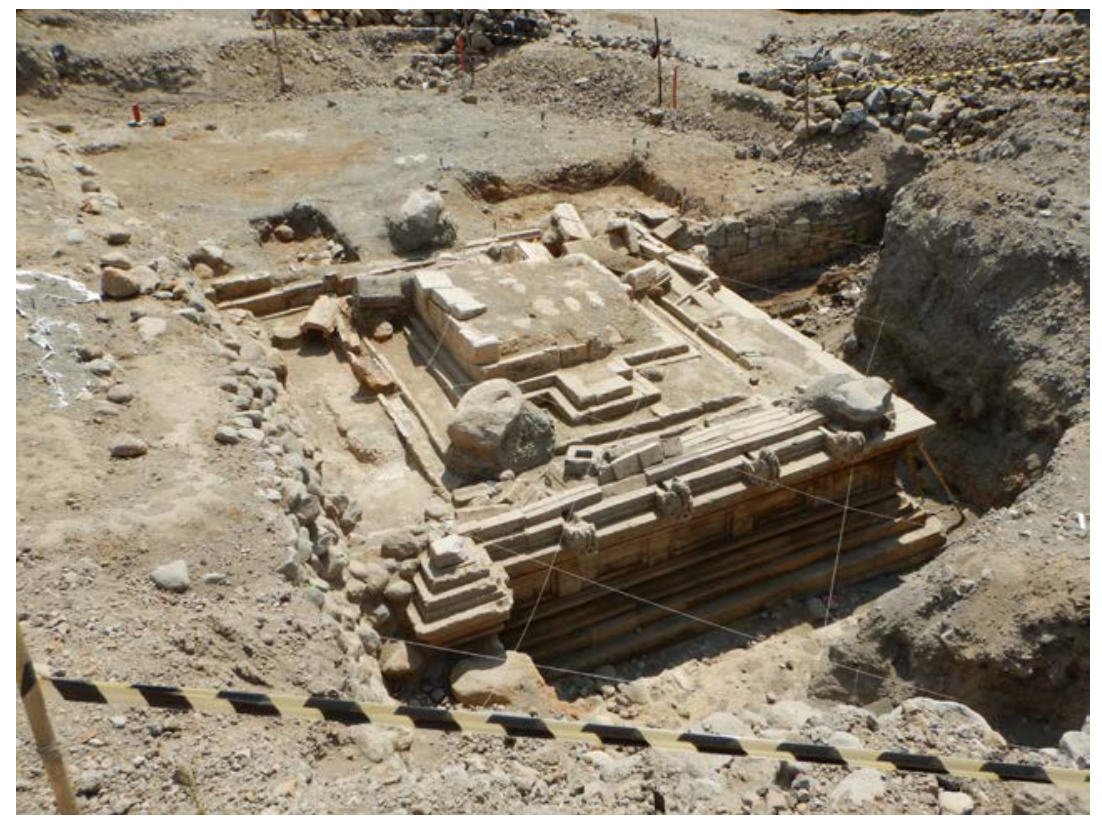

Gambar 2. Bangunan Petirtaan di Teras Pertama Situs Liyangan (Sumber: Daud Aris Tanudirjo)

Di teras kedua, terdapat satu struktur batur dengan kaki tinggi (sekitar 1,5 $\mathrm{m})$. Struktur ini sering disebut sebagai bangunan Candi I dalam laporan penelitian Balai Arkeologi Yogyakarta. Susunan batu-batu pada struktur ini masih sangat

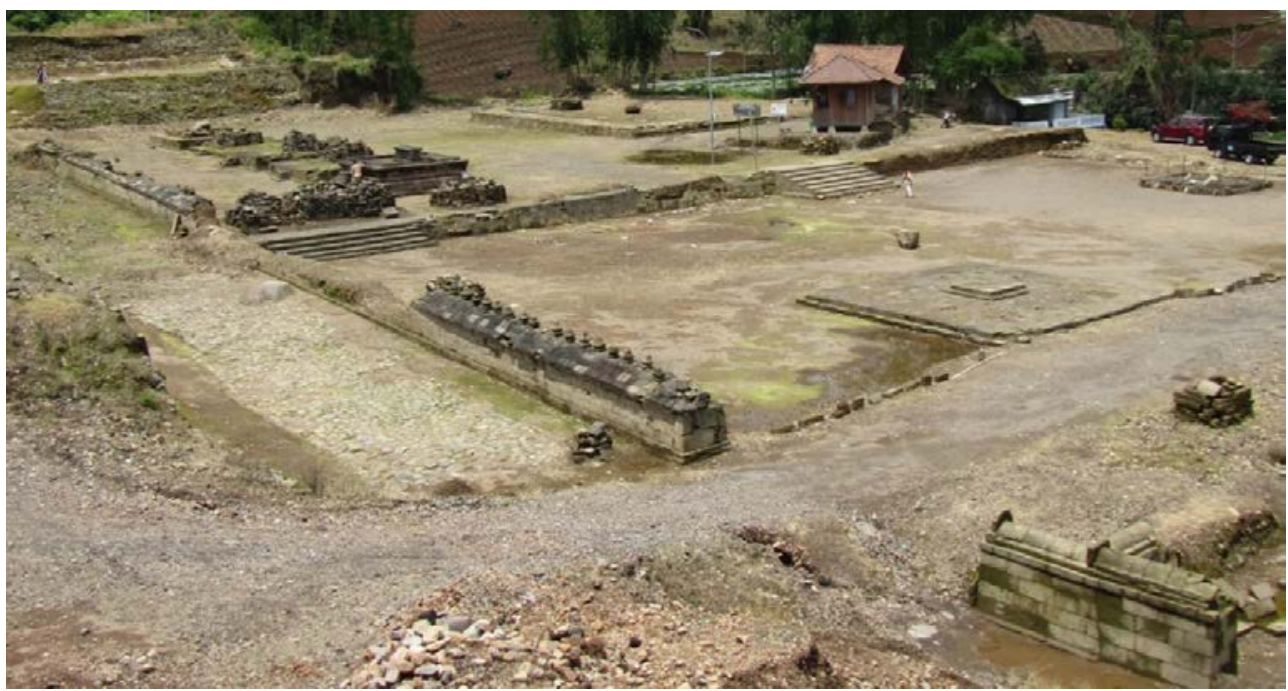

Gambar 3. Temuan sejumlah struktur batu di teras ketiga dan keempat (Sumber: Daud Aris Tanudirjo) 
solid, sehingga diyakini masih dalam kondisi asli termasuk jejak atau sisa dinding pada ambang pintu yang dapat dikenali.

Di teras ketiga, yang dibatasi dengan talud balok batu persegi, terdapat setidaknya dua struktur batur (disebut Batur 1 dan Batur 4). Pada bagian penggal sisi barat laut talud teras ketiga ini terdapat struktur jalan balok batu yang menghubungkan antara teras kedua dan ketiga. Jalan balok batu ini tidak bertangga, tetapi rata menurun (Gambar 3).

Di teras keempat terdapat enam struktur batur batu. Lima struktur batur yang berukuran hampir sama, semuanya menghadap ke tenggara, berdiri berjajar arah timur laut - barat daya. Kelima batur ini terletak di bagian arah tenggara halaman dekat dengan pagar balok batu. Pengamatan cermat terhadap bagianbagian struktur batu ini dapat memastikan keadaan struktur masih sangat solid, tidak mengalami pergeseran arah, dan masih menyisakan keberadaan tangga dan jejak orientasi pintu. Sementara itu, di halaman teras ini juga, tepatnya di sebelah barat laut deretan lima batur, terdapat satu batur yang berukur paling besar. Sisi barat laut batur ini sebagian terkikis oleh Sungai Langit yang mengalir dekat batur ini. Posisi struktur ini juga menunjukkan tidak ada pergeseran (Gambar 4).

Di teras kelima, yang ditalud dengan batu-batu bulat, tidak terdapat bangunan. Bagian ini hanya berupa halaman teras sempit sekitar 3 meter. Teras ke enam ditalud dengan batu-batu bulat. Sebagian halaman teras ini telah dikikis oleh aliran Sungai Langit sehingga mengesankan teras ini terpisahkan dari teras kelima. Dengan kata lain, teras keenam berada di seberang Sungai Langit. Karena kondisi tersebut, keadaan pada halaman teras ini masih sulit untuk

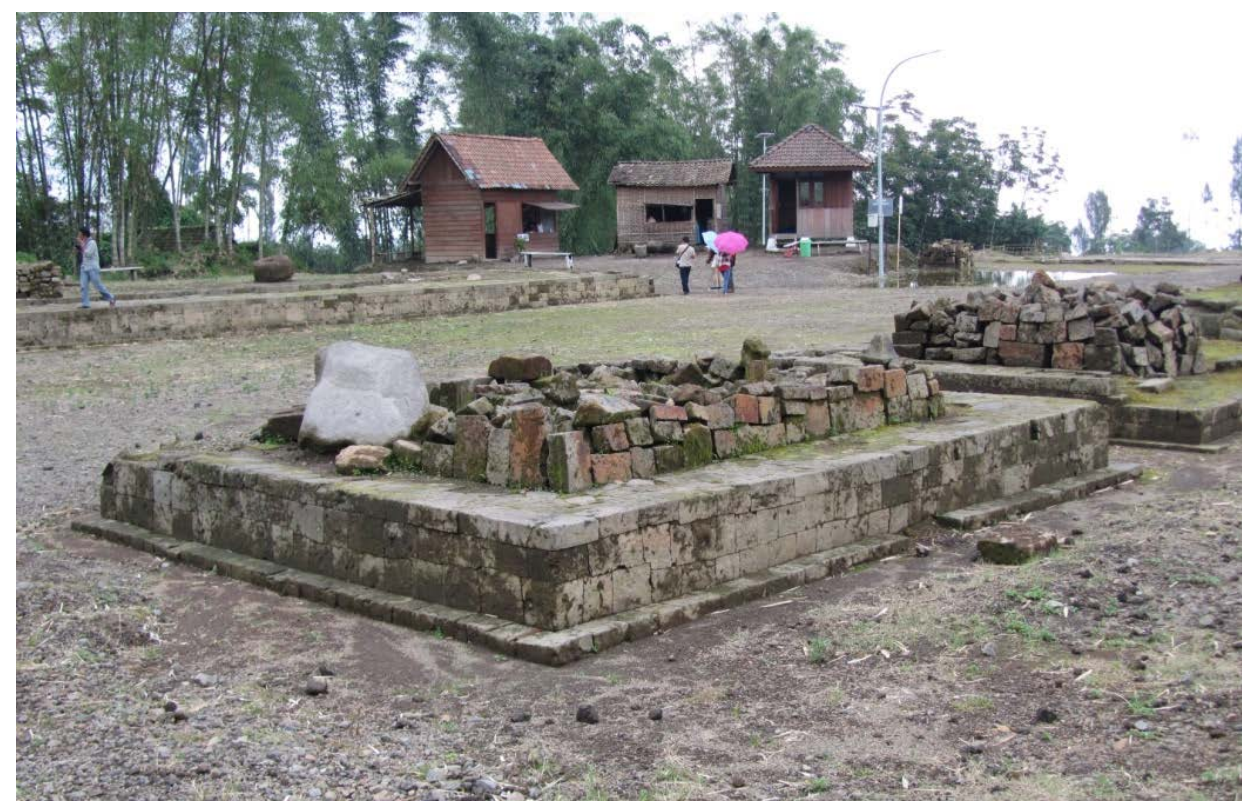

Gambar 4. Salah satu struktur batur batu di teras keempat Situs Liyangan (Sumber: Daud Aris Tanudirjo)

direkonstruksi. Mungkin sekali halaman teras ini justru merupakan tempat asal dari sejumlah temuan artefaktual yang dilaporkan tahun 2008, antara lain berupa yoni, arca dan benda logam. Temuan-temuan ini kini berada di sisi barat laut halaman teras di bawah talud teras ketujuh. 
Teras ke tujuh disangga oleh talud yang berdinding balok batu persegi (temuan tahun 2008). Sebagian besar talud ini sudah hancur akibat proses penambangan. Di lokasi yang diduga merupakan halaman teras ke tujuh terdapat setidaknya satu yoni berukuran cukup besar dan beberapa batu persegi yang mungkin sekali bagian dari candi. Di bagian atas teras ini, yang kini telah menjadi lahan pertanian, juga terdapat fragmen yoni dan batu candi. Dari pengamatan foto-foto dokumentasi pada teras ini, diketahui bahwa sesungguhnya di teras ini juga terdapat beberapa talud batu bulat. Namun, akibat penambangan dan aktivitas pertanian, talud-talud ini sudah sulit dikenali lagi saat ini.

Berbagai data yang telah dikumpulkan di Situs Liyangan dan dirisalahkan di atas setidaknya mampu memberikan gambaran yang cukup kuat bahwa Situs Liyangan adalah situs permukiman yang cukup lengkap dan jarang ditemukan di Indonesia. Situs ini dapat memberikan contoh permukiman Masa Klasik (pengaruh Budaya Hindu) di Jawa, yang memiliki unsur-unsur bangunan sakral maupun profan. Pola permukiman tersusun menjadi teras-teras yang dibatasi oleh talud dari balok batu persegi empat dan/atau batu-batu bulat. Meskipun orientasi situs secara keseluruhan mengikuti pola lereng mengarah ke Gunung Sindoro (timur laut - barat daya), tetapi beberapa bangunan utamanya justru berorientasi ke arah tenggara - barat laut. Hasil pengukuran orientasi sepuluh struktur yang menjadi sampel dalam penelitian ini dapat dilihat pada Tabel 1.

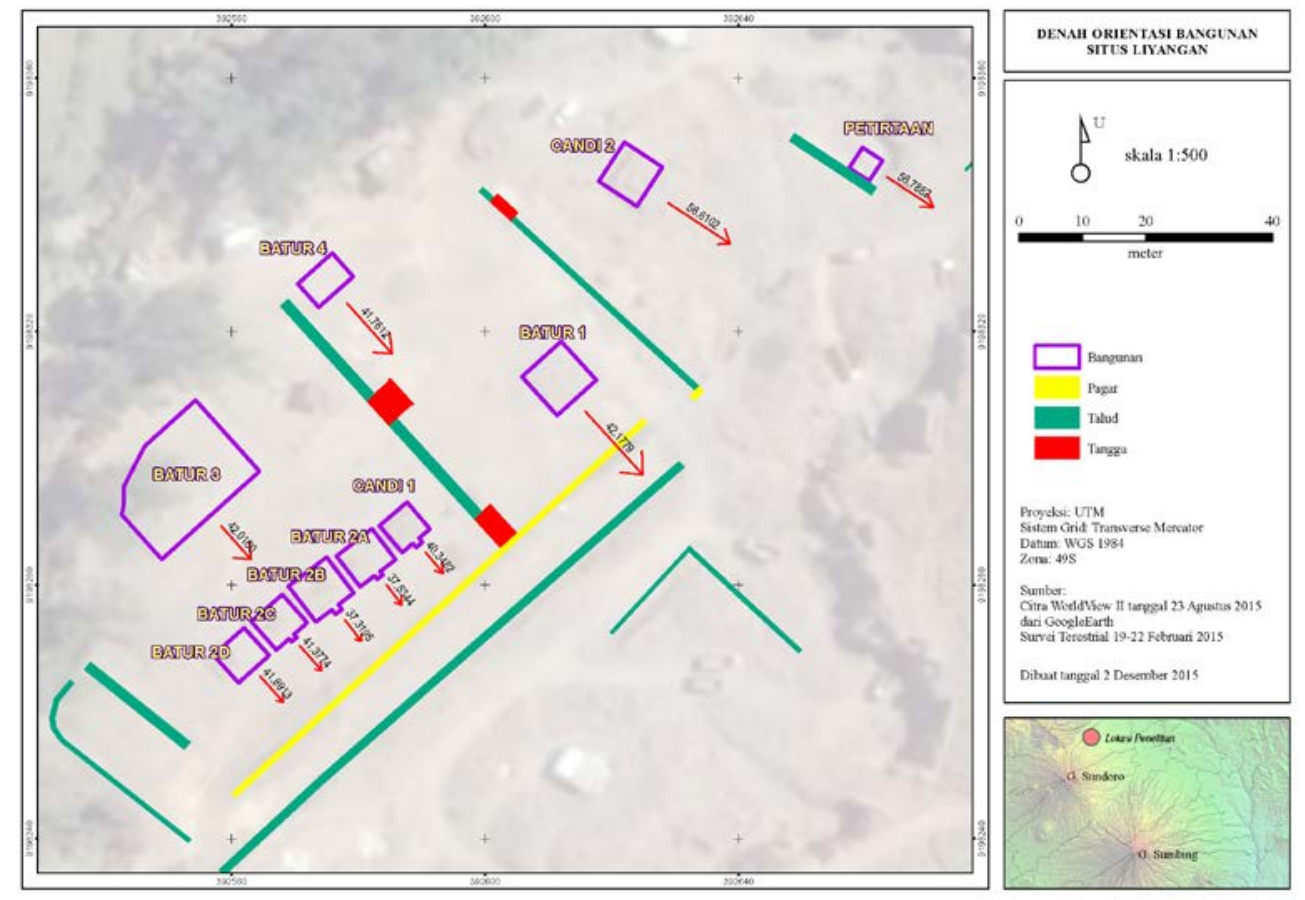

Gambar 5. Orientasi sepuluh struktur batu di Situs Liyangan (Sumber: Tim Penelitian UGM 2015) 
Tabel 1. Derajat orientasi sepuluh struktur batu di Situs Liyangan

\begin{tabular}{ccccc}
\hline No. & Nama Bangunan & $\begin{array}{c}\text { Polar Angle* } \\
\text { (derajat) }\end{array}$ & $\begin{array}{c}\text { North Azimuth }^{\star *} \\
\text { (derajat) }\end{array}$ & $\begin{array}{c}\text { South Azimuth } \\
\text { (derajat) }\end{array}$ \\
\hline 1. & Petirtaan & 326.7882 & 123,2118 & 56.7882 \\
\hline 2. & Candi 2 & 326.6102 & 123,3898 & 56.6102 \\
\hline 3. & Batur 1 & 312.1779 & 137,8221 & 42.1779 \\
\hline 4. & Batur 4 & 311.7612 & 138,2388 & 41.7612 \\
\hline 5. & Batur 3 & 312.016 & 137,9840 & 42.016 \\
\hline 6. & Candi 1 & 310.3482 & 139,6518 & 40.3482 \\
\hline 7. & Batur 2a & 307.5344 & 142,4656 & 37.5344 \\
\hline 8. & Batur 2b & 307.3195 & 142,6805 & 37.3195 \\
\hline 9. & Batur 2c & 311.3774 & 138,6228 & 41.3774 \\
\hline 10. & Batur 2d & 311.8913 & 138,1087 & 41.8913 \\
\hline
\end{tabular}

Catatan:

* Penghitungan menggunakan sistem sudut kutub (polar angle system),

** Hasil konversi ke sistem arah azimuth utara (north azimuth system, dibaca searah jarum jam)

*** Hasil konversi ke sistem arah azimuth selatan (south azimuth system, dibaca

berlawanan arah jarum jam)

\section{DISKUSI DAN PEMBAHASAN}

Untuk dapat memahami secara lebih mendalam mengenai orientasi struktur-struktur batu di Situs Liyangan yang berbeda dari kebanyakan bangunan "candi" lainnya di Jawa Tengah yang sejaman, diperlukan kajian terhadap konteks waktu, budaya, maupun keruangan yang terkait dengan keberadaan Situs Liyangan . Kajian tersebut diperlukan untuk memberikan latar budaya dan alam Situs Liyangan sebagaimana yang dibutuhkan dalam kajian arkeologi lanskap.

Terkait konteks waktu, hingga saat ini, belum ada kepastian yang meyakinkan untuk meletakkan Situs Liyangan dalam konteks sejarah di Pulau Jawa. Meskipun sejumlah pertanggalan absolut sudah diperoleh dari situs ini, tetapi tatacara penyajiannya yang tidak akurat menyulitkan penafsiran yang lebih tepat. Konteks waktu keberadaan permukiman Liyangan secara teoritis dapat diperoleh dari sejumlah data pertanggalan dari temuan kubur manusia, temuan artefaktual, maupun peristiwa erupsi. Namun, sejauh ini data pertanggalan yang ada justru menimbulkan kerumitan penafsiran atau bahkan kerancuan.

Sebagaimana disebutkan di atas, pertanggalan tertua yang diperoleh dari Situs Liyangan berasal dari matriks tanah temuan rangka manusia memberikan pertanggalan $2231 \pm 25 \mathrm{BP}$, atau sekitar abad ke 2 atau ke-3 Sebelum Masehi. Namun, bisa jadi pertanggalan ini lebih menunjukkan umur tanahnya daripada rangka manusianya (Noerwidi, 2014), sehingga mungkin kurang tepat digunakan untuk pertanggalan situs permukiman Liyangan itu sendiri. Kajian yang lebih 
teliti untuk mengungkap keberadaan dan keterkaitan temuan rangka dan permukiman Liyangan rupanya masih perlu dilakukan.

Sementara itu, kajian erupsi Gunungapi Sindoro pun memberikan kerangka waktu yang tidak sepenuhnya dapat digunakan untuk menentukan secara tepat kapan Situs Liyangan terkubur. Ada berbagai hasil penelitian yang telah mencoba mengidentifikasikan proses erupsi Gunungapi Sindoro. Data pertanggalan dari arang kayu pada lapisan aliran piroklastik memberikan pertanggalan \pm 1.720 tahun (Sukhyar, 1992; Nurnusanto, 2014), Apabila dikonversikan ke tahun Masehi, berada di sekitar $230 \mathrm{M}$.

Data erupsi Gunungapi Sindoro dapat diperoleh juga dari risalah yang disusun oleh Wunderman (2013) yang menyebutkan setidaknya ada sebelas erupsi yang diketahui terjadi hingga tahun 1971. Dua di antara erupsi tersebut cukup relevan dikaitkan dengan endapan piroklastik di Situs Liyangan , yaitu erupsi tahun $230 \mathrm{M}$ dan $470 \mathrm{M}$. Disebutkan, erupsi tahun $230 \mathrm{M}$ telah mengalirkan material piroklastik ke lereng timur laut sejauh lebih dari $13 \mathrm{~km}$ dari puncak dan menghasilkan Endapan Aliran Piroklastik 5 Sundoro (atau Sap 5) pada peta geologi Sukhyar dkk. (1992). Situs Liyangan memang terletak tepat di pinggiran aliran piroklastik ini. Sebagian lapisan ini tertimbun endapan piroklastik Sap-5 dan Sap-6 yang merupakan aliran piroklastik termuda yang mengalir ke lereng timur. Selanjutnya, erupsi terjadi kembali pada sekitar 470 M (Wunderman, 2013) atau 1480 tahun yang lalu. Dari peta geologi (Sukhyar dkk., 1992) dapat diketahui bahwa aliran Sap-6 tidak terdapat di Situs Liyangan. Lagipula, kedua pertanggalan ini masih terlalu awal jika dibandingkan data artefaktual yang menempatkan erupsi yang mengubur Situs Liyangan pada kurun waktu abad ke-9 atau ke-10. Pada bagian lain risalah versi Wunderman ini juga disebutkan erupsi berikutnya terjadi tahun 1806, 1818, 1882, dan 1883 M. Sayangnya, informasi tentang rangkaian erupsi tersebut tidak banyak didapat, meskipun disebutkan pula erupsi yang terjadi pada tanggal 1 - 7 April 1882 mengarah ke bagian puncak, lereng timur laut dan barat laut Gunungapi Sindoro (Wunderman, 2013). Dari amatan pada peta geologi pun lagi-lagi tidak tergambarkan erupsi puncak ini meninggalkan jejak endapan material erupsi pada tahun itu pada lapisan geologi di Situs Liyangan.

Sejumlah pertanggalan C-14 dari arang yang diduga terbakar ketika terlanda aliran piroklastik juga diperoleh sebagai hasil penelitian beberapa tahun terakhir ini, diantaranya disebutkan 587, 742, 846, 913, dan 971 Masehi [sic] (Riyanto, 2014b, hlm. 100). Data dari sumber sekunder ini tidak memuat informasi yang cukup lengkap, antara lain tidak ada informasi tentang jenis materi sampel yang dipertanggalkan, laboratorium tempat sampel dianalisis, nilai tengah dan kisaran deviasi pertanggalannya, posisi stratigrafis, maupun terkalibrasi atau tidak-nya pertanggalan tersebut. Ketiadaan informasi itu menyulitkan penafsiran secara lebih rinci.

Publikasi terbaru tentang erupsi Gunungapi Sindoro (Prambada, dkk. 2016) menyebutkan setidaknya ada 12 erupsi sejak 34.000 tahun lalu, yang dapat dikenali berdasarkan lapisan endapan yang terdapat di sejumlah tempat. Erupsi yang cukup relevan dikaitkan dengan kurun waktu bencana yang diduga mengubur permukiman kuno Liyangan adalah erupsi Liyangan pada kurun waktu 1280 - 1180 BP (sekitar $670-770 \mathrm{M}$, tak terkalibrasi) dan erupsi Kledung pada kurun waktu 1095 - 979 BP (sekitar 855 - 971 M, tak terkalibrasi). Setelah 
kedua erupsi tersebut, memang tercatat adanya erupsi lain yaitu erupsi Puncak dan erupsi Sibayak pada ancangan waktu 515 - 453 BP (sekitar 1435 - 1507 M, tak terkalibrasi), serta erupsi tahun 1806 . Namun, ketiga erupsi yang dicatat terakhir tidak mengarah ke lereng timur laut.

Hasil identifikasi erupsi terbaru ini (Prambada dkk., 2016) tampaknya memberikan kerangka waktu yang lebih sesuai dengan hasil analisis temuan artefaktual. Kebanyakan artefak yang terkubur dalam endapan Liyangan memang berasal dari abad ke-9 atau bahkan mungkin abad ke-10. Pertanggalan ini memberikan terminus post quem untuk erupsi yang mengubur Situs Liyangan. Tentunya, jika pertanggalan relatif temuan artefaktual itu benar, maka aliran piroklastik di Situs Liyangan pasti terendapkan setelah abad ke-9 atau setidaknya dalam abad ke-10.

Informasi lain diperoleh dari kajian data sekunder, dari catatan ahli geologi R. van Bemmelen (1949) yang konon menyebutkan adanya erupsi Gunungapi Sindoro pada tahun 1600 - 1617 M (Fadlan, 2014, hlm. 136). Erupsi ini disebutkan telah menghancurkan kampung-kampung di lerengnya. Tim peneliti mencoba melacak rujukan ini, tetapi hingga kini belum dapat mengkonfirmasikan kebenaran informasi ini. Apakah informasi ini dapat dikaitkan dengan erupsi Sibayak yang disebut dalam risalah erupsi versi Prambada dkk. (2016) terjadi antara 1435 - $1507 \mathrm{M}$ (lihat di atas) belum dapat dipastikan juga, karena endapan erupsi Sibayak cenderung ke arah tenggara, bukan ke timur laut. Jika catatan Bemmelen memang benar, agak mengherankan juga apabila endapan erupsi cukup besar itu tidak teridentifikasikan oleh penelitian Prambada, dkk., yang cukup komprehensif.

Dengan menyandingkan rangkaian informasi tentang kemungkinan erupsi yang melanda Situs Liyangan , dapat disimpulkan di sini, setidaknya untuk sementara, erupsi yang melanda Situs Liyangan terjadi dalam atau sesudah abad ke-10. Sejumlah erupsi cukup signifikan masih juga terjadi setelah abad ke-10, dengan kemungkinan pada abad ke-15 atau ke-16. Kesimpulan sementara ini menjadi penting terkait dengan hasil pengamatan tim peneliti yang melihat kemungkinan adanya dua tahap hunian di Situs Liyangan. Ada beberapa hasil pengamatan yang memperkuat dugaan tersebut.

Pertama, dinding-dinding talud terdiri dari dua jenis, yaitu talud balok batu dan talud batu bulat. Di beberapa tempat, talud balok batu berselang-seling dengan talud batu bulat yang memberikan kesan kuat adanya perbaikan talud balok batu yang rusak dengan talud batu bulat. Kedua, fenomena perbaikan seperti itu juga tampak dari tembok-tembok teras halaman Situs Liyangan. Di beberapa bagian teras-teras ini terlihat adanya perbedaan bahan batu penyusun dan cara pengerjaannya. Ada batu penyusun yang berbahan lebih segar (fresh) dan dikerjakan dengan cukup baik, tetapi ada pula balok batu yang sudah mengalami kelapukan dan keausan yang cukup kentara. Hal ini menunjukkan ciri pengerjaan dalam waktu yang cukup berbeda.

Ketiga, dari berbagai bangunan dan struktur yang ditemukan, setidaknya ada dua gaya arsitektural yang berbeda. Bangunan petirtaan dan Candi 2 menunjukkan bahan dan pengerjaan lebih awal, sedangkan Candi 1 dan baturbatur lainnya yang terdapat pada teras keempat dikerjakan dengan bentuk yang lebih sederhana dan cenderung minimalis. Kenampakan patina pada kedua kelompok struktur tadi juga berbeda. Perbedaan berikutnya ada pada 
orientasinya. Candi 2 dan Pertirtaan berorientasi $56.6102^{\circ}$ dan $56.7882^{\circ}$ (setelah dikonversi, lihat pada tabel hasil pengukuran), sedangkan orientasi Candi 1 dan semua batur lainnya berkisar antara $37.3195^{\circ}$ dan $42.1939^{\circ}$ (lihat Tabel 1).

Pengamatan terhadap temuan-temuan di atas mengarahkan pada kemungkinan Situs Liyangan pernah dihuni setidaknya dua tahap dan terkena bencana setidaknya dua kali juga. Bencana awal terjadi pada sekitar abad ke-9 atau ke-10, ketika situs ini tertimbun material aliran piroklastik endapan Liyangan dan Kledung. Kemudian, setelah beberapa saat, permukiman itu ditemukan dan bagian-bagian tertentu dipugar kembali dengan tambahan sejumlah talud untuk memperkuat dinding tebing yang terbentuk akibat erupsi. Namun, pada abad ke15 atau ke-16 (?) permukiman ini terlanda lagi oleh aliran piroklastik sehingga terkubur kembali sampai akhirnya ditemukan oleh para penambang pasir-batu sejak tahun 2000 lalu (bandingkan Riyanto, 2014b; Fadlan, 2014, hlm. 138-141). Kecenderungan untuk kembali menempati permukiman lama, meskipun telah terlanda bencana, merupakan fenomena umum di banyak budaya sebagaimana dikemukakan oleh Sheet (2007).

Konteks budaya suatu temuan arkeologis umumnya ditentukan berdasarkan atas hasil kajian artefaktual yang ada. Gaya atau langgam artefak yang ditemukan dapat menjadi petunjuk konteks budaya temuan tersebut. Dalam kasus Situs Liyangan, sejumlah besar temuan baik berupa struktur bangunan batu, arca lepas, keramik asing, dan benda logam perunggu pada umumnya mengarah pada langgam budaya Masa Klasik, yang berlangsung antara abad ke7 hingga ke-10 M. Namun, sayang sekali lebih banyak temuan tersebut diperoleh karena aktivitas pertambangan daripada aktivitas penelitian arkeologis. Akibatnya, konteks setiap temuan itu menjadi tidak diketahui dengan pasti. Namun, laporan survei geologi di situs ini (Putra, dkk., 2013) menyebutkan bahwa kebanyakan temuan keramik dan anyaman bambu terbakar berada pada endapan aliran priroklastik 1 (lebih awal atau pada lapisan bawah). Sebaliknya, dari pengamatan di lapangan, di dalam endapan awan panas 2 (lapisan atas) pun terdapat cukup banyak temuan anyaman bambu dan kayu yang terbakar dan juga beberapa artefak logam yang langgamnya tampak lebih baru, di antaranya sabit, parang, cangkul, "tang" (penjepit), dan bahkan unsur hiasan bangunan kayu yang dibuat dengan teknik bubut (Riyanto, 2014b). Tidak jelasnya konteks setiap temuan memang menyulitkan analisis yang lebih rinci dan memastikan konteks budaya setiap jenis temuan itu dengan lebih akurat.

Jika diamati lebih teliti, beberapa arca yang ditemukan di Situs Liyangan dan bangunan Candi 1, ternyata temuan-temuan itu tidak menunjukkan langgam Masa Klasik yang baku. Beberapa arca batu, di antaranya arca Ganesha dan Nandi tidak menunjukkan ciri ikonografis yang baku, khususnya dalam hal proporsi, dan tampak dibuat dengan sederhana (lihat foto-foto dalam tulisan Istari, 2014). Biasanya arca-arca seperti ini dibuat sebagai karya pinggiran atau jauh dari pusat pemerintah. Kemungkinan lain, langgam arca seperti itu muncul pada masa setelah pengaruh Hindu surut. Demikian pula dengan Candi 1 yang terdiri atas bagian batur dan lapik persegi yang di atasnya terdapat tiga lubang. Di lubang tengah terdapat batu lingga, sehingga lapik ini seringkali disebut sebagai Yoni. Meskipun dari langgam profil kaki candi-nya, bangunan ini disebut memiliki langgam Jawa Tengah, tetapi paduan dengan lapik menyerupai altar berlubang tidak lazim pada periode itu. Bentuk semacam altar tersebut juga muncul setelah 
Hindu tidak menjadi agama arus utama dan bercampur dengan kepercayaan tradisional, seperti misalnya temuan arca-arca di lereng barat Gunung Lawu dan Gunung Penanggungan. Keadaan ini semakin membuka peluang untuk mendukung tafsiran adanya dua konteks budaya, yaitu Masa Klasik Jawa Tengah sebagai arus utama pada tahap awal dan budaya akhir pengaruh Hindu.

Pada Masa Klasik Jawa Tengah (abad ke-7 hingga ke-10), Situs Liyangan bisa jadi merupakan salah satu wanua (desa) di bawah kekuasaan Kerajaan Mataram Hindu (abad ke-7 hingga abad ke-10). Dari berbagai sumber sejarah, diketahui bahwa ibukota kerajaan ini setidaknya ada tiga yaitu Mataram, Mamatri, dan Poh Pitu (Muljana, 2006; Casparis, 1956). Muljana menduga pusat Kerajaan Mataram awalnya ada ada di bagian utara Yogyakarta atau sekitar Sleman, di sisi barat daya Gunung Merapi. R.M. Poerbatjaraka (1952) juga pernah mengidentifikasi pusat Mataram di Sleman dengan menafsirkan kata "kunjarakunjadesa" dalam Prasasti Canggal (732 M). Ahli filologi ini menyamakan kata itu dengan Saliman atau Sleman (bandingkan dengan Tanudirjo, 2011).

Mengenai lokalisasi Mamatri ada perbedaan di antara beberapa ahli. Muljana (2006) lebih cenderung meletakkan di daerah Temanggung, sedangkan Boechari menempatkannya di sekitar Prambanan. Mamatri diketahui menjadi pusat kerajaan pada masa pemerintahan Rakai Kayuwangi (856-886 M). Mengingat raja ini sering dikaitkan sebagai pendiri Kompleks Candi Prambanan (Casparis, 1956), tampaknya kemungkinan Mamatri berada di sekitar Prambanan lebih masuk akal. Sebelum Raja Kayuwangi, pendahulunya Raja Pikatan (847-856 M) memerintah dari ibukota yang disebut sebagai Poh Pitu. Menurut Muljana (2006), pusat kerajaan ini juga berada di Temanggung atau Mantyasih. Jejak-jejak tinggalannya terdapat di sekitar sumberair Pikatan sekarang. Sementara itu, nama Mantyasih masih terdapat di utara Kedu. Keletakan desa-desa (wanua) Mataram Hindu di sekitar Temanggung dan Kedu pernah dijelaskan oleh Casparis (1950) dan rekonstruksi toponim kuno di masa kini dilakukan oleh Resiyani (2010). Dari kajian nama-nama desa tersebut, konteks budaya Situs Liyangan sebelum abad ke-10 semestinya tidak jauh dari pusat Kerajaan Mataram Hindu di Poh Pitu.

Penempatan Situs Liyangan dalam konteks budaya Mataram Hindu menjadi makin kuat apabila mempertimbangkan berbagai temuan arkeologis yang ada di sekitarnya. Ada sejumlah situs candi penting berada tidak jauh dari Situs Liyangan (mengenai rincian temuan lihat Yuwono, 2013), antara lain Candi Pringapus, Candi Perot, Candi Bongkol, Candi Bagusan, reruntuhan Candi Gondosuli, serta Pemandian Pikatan. Sejumlah prasasti Mataram Hindu juga ditemukan di daerah ini di antaranya prasasti Gondosuli (832 M), Tulang Air (850 M), Mantyasih (907 M), Rukam (907 M) dan Wanua Tengah (908 M). Selain itu, di sebelah barat laut Situs Liyangan terdapat kompleks percandian Dieng yang dibangun lebih awal dari candi-candi lain yang ada di wilayah Temanggung.

Dalam konteks ini memang amat menarik untuk mengaitkan Situs Liyangan dengan Prasasti Rukam yang diterbitkan tahun 907 M. Selain menyebutkan adanya desa yang hancur karena erupsi gunungapi, prasasti ini juga menyebutkan kewajiban Desa Rukam untuk memelihara dan memberi persembahan kepada bangunan suci di Limwung. Saat ini, hanya sekitar $5 \mathrm{~km}$ lurus dari Situs Liyangan terdapat Desa Limbung yang kemungkinan adalah lokasi Limwung dalam prasasti tersebut. Meskipun demikian, harus diakui hingga kini masih sulit dibuktikan antara Situs Liyangan dengan desa yang 
hancur dalam Prasasti Rukam. Masih perlu dilakukan pembacaan kembali terhadap prasasti ini apabila ingin mengungkapkan lebih jauh hubungannya dengan Situs Liyangan.

Mengenai konteks keruangan Situs Liyangan, pengamatan dan kajian terhadap data geologis menunjukkan bahwa Situs Liyangan berada pada tepian jalur aliran piroklastik. Situs itu sendiri menempati punggungan bukit yang diapit oleh dua lembah di kanan-kirinya. Dari pengamatan pola distribusi endapan di sekitar situs, yang dapat dibedakan menjadi endapan aliran dan jatuhan piroklastik, mungkin sekali awalnya permukiman purba Liyangan didirikan pada permukaan tanah yang dihasilkan dari jatuhan piroklastik di tepi lembah. Namun, ketika volume aliran piroklastik pada erupsi berikutnya begitu besar dan tidak tertampung di lembah, maka meluap hingga menimbun permukiman yang ada (bandingkan dengan Fadlan, 2014, hlm. 138-141). Jadi, sebelum tertimbun, pandangan dari permukiman Liyangan ke arah tenggara akan jauh lebih terbuka dan leluasa, termasuk untuk melihat rangkaian Gunung Sumbing, Merbabu dan Merapi.

Berdasarkan pada luasan permukiman dan keberagaman temuan yang ada, cukup layak sekiranya Situs Liyangan ditafsirkan sebagai permukiman yang merupakan bagian dari satu wanua atau desa di masa Mataram Hindu. Menurut Christie (1990) wanua dapat berarti: (a) komunitas yang tinggal di suatu tempat dan mempunyai organisasi internal tertentu, atau (b) satuan luasan tanah tertentu yang merupakan wilayah kekuasan komunitas tersebut. Komunitas ini memiliki stratifikasi sosial dengan hak-hak tanah yang diperoleh dari leluhur mereka yang didewakan dan dipuja dengan menggunakan watu kulumpang (lumpang batu yang sakral). Melalui pemujaan itu, nenek moyang dianggap sebagai sumber hidup dan kesuburan. Dari telaah sejumlah prasasti, Christie memperkirakan luas wanua hampir sama dengan desa tradisional Jawa saat ini. Selain ada sawah yang luas, berkisar antara 120-180 hektar, wanua tentu memiliki perkampungan untuk tempat tinggal. Rumah-rumah di kampung biasanya dimiliki oleh pribadi atau satu keluarga inti. Jika tafsiran Christie dapat diterima, maka Situs Liyangan memang hanya bagian permukiman dari suatu wanua yang sering disebut sebagai pomahan. Sisa-sisa bangunan kayu dan temuan beragam peralatan hidup, serta adanya prasarana peribadatan di situs ini dapat menunjukkan fungsi situs sebagai perkampungan.

Dalam konteks ruang geografis yang lebih luas, Situs Liyangan dapat dimasukkan ke dalam tipe situs pedalaman, karena letaknya yang relatif jauh dari pesisir, yaitu sekitar $30 \mathrm{~km}$. Apalagi kedudukannya di lereng gunung yang cukup tinggi, antara 1100-1200 m dpl. Meskipun demikian, banyaknya temuan barangbarang dari luar, seperti keramik, kaca, manik-manik, dan benda-benda ideofak perunggu, membuktikan bahwa akses ke dunia luar cukup lancar. Selain itu, benda-benda 'impor' itu menunjukkan kemampuan ekonomi penghuni permukiman kuno Liyangan. Keadaan ini barangkali berkaitan pula dengan letak permukiman tersebut yang berada tidak jauh dari ibukota (Mochtar, 2014, hlm. 156-159). Selain itu, lokasi situs ini juga berada jalur pergeseran pusat-pusat kekuasaan pada jalur poros Dieng - Temanggung - Kedu - Sleman - Kewu (Prambanan). Berdasarkan lokasinya yang strategis ini, dapat diperkirakan permukiman kuno Liyangan menempati posisi yang cukup penting dalam konstelasi jaringan kekuasaan Mataram Hindu. 


\section{Lanskap Spiritual Situs Liyangan}

Sebaran temuan struktur dan bangunan batu di Situs Liyangan menunjukkan arah pomahan (kampung) itu mengikuti kelerengan kaki Gunungapi Sindoro. Ini merupakan bentuk adaptasi teknis terhadap bentang alamnya. Terasteras memang cara paling mudah untuk memecahkan perbedaan ketinggian (kontur) permukaan tanah. Namun, jika mempertimbangkan arah orientasi sejumlah struktur yang telah diukur sebelumnya, dapat dikatakan permukiman kuno Liyangan tidak diarahkan ke puncak Gunung Sindoro. Dengan kata lain, sejumlah teras yang semakin tinggi hanya cerminan solusi teknologis, dan bukan orientasi spiritual religius permukiman ini. Tentunya, tidak juga mengikuti konsep kaja - kelod seperti di Bali maupun konsep pemujaan leluhur pra-Hindu yang biasanya diarahkan ke puncak gunung terdekat (dalam hal ini Gunung Sindoro).

Lalu, apakah pengarahan struktur-struktur batu yang diduga sisa bangunan suci itu ke tenggara dimaksudkan untuk memuja dewa tertentu? Dalam konsep agama Hindu memang dikenal dewa-dewa yang dianggap menduduki arah-arah mataangin tertentu. Para dewa ini dikenal sebagai Dewa Lokapala atau dewa penjaga arah mata angin. Para Dewa Lokapala tersebut adalah sebagai berikut (Lohuizen de Leeuw, 1955).

Tabel 2. Konstelasi Dewa Lokapala menurut Lohuizen de Leeuw (1955)

\begin{tabular}{|l|c|}
\hline \multicolumn{1}{|c|}{ Arah Mata Angin } & Nama Dewa \\
\hline Utara & Kuvera \\
\hline Utara - Timur Laut & Visvakarman \\
\hline Timur Laut - Timur & Isana \\
\hline Timur & Indra \\
\hline Timur - Tenggara & Brhaspati \\
\hline Tenggara & Agni \\
\hline Tenggara - Selatan & Yamana \\
\hline Selatan & Brahmanaspati \\
\hline Selatan - Barat Daya & Nairrta \\
\hline Barat Daya & Surya \\
\hline Barat Daya - Barat & \\
\hline
\end{tabular}

Apabila mengikuti kedudukan Dewa-dewa Lokapala, maka arah hadap tenggara ditempati oleh Dewa Agni. Hanya saja, benda-benda ideofak yang ditemukan di Situs Liyangan sejauh ini belum dapat mengonfirmasikan dugaan ini. Sebaliknya, pengukuran orientasi yang dilakukan dalam penelitian ini justru memberikan hasil yang mengejutkan. Apabila sudut arah kiblat setiap bangunan ditarik menjadi garis lurus yang cukup panjang pada lanskap budaya Mataram Hindu yang lebih luas, maka dapat diperoleh tiga arah orientasi yang berbeda. Petirtaan dan Candi 2 yang diperkirakan merupakan struktur batu yang lebih tua 
dibandingkan dengan yang lainnya mengarah ke puncak Gunungapi Merapi, struktur batu Candi 1 dan tiga struktur batur batu di teras keempat mengarah ke Candi Prambanan, dan dua struktur lainnya (Batur 2a dan 2b) kemungkinan

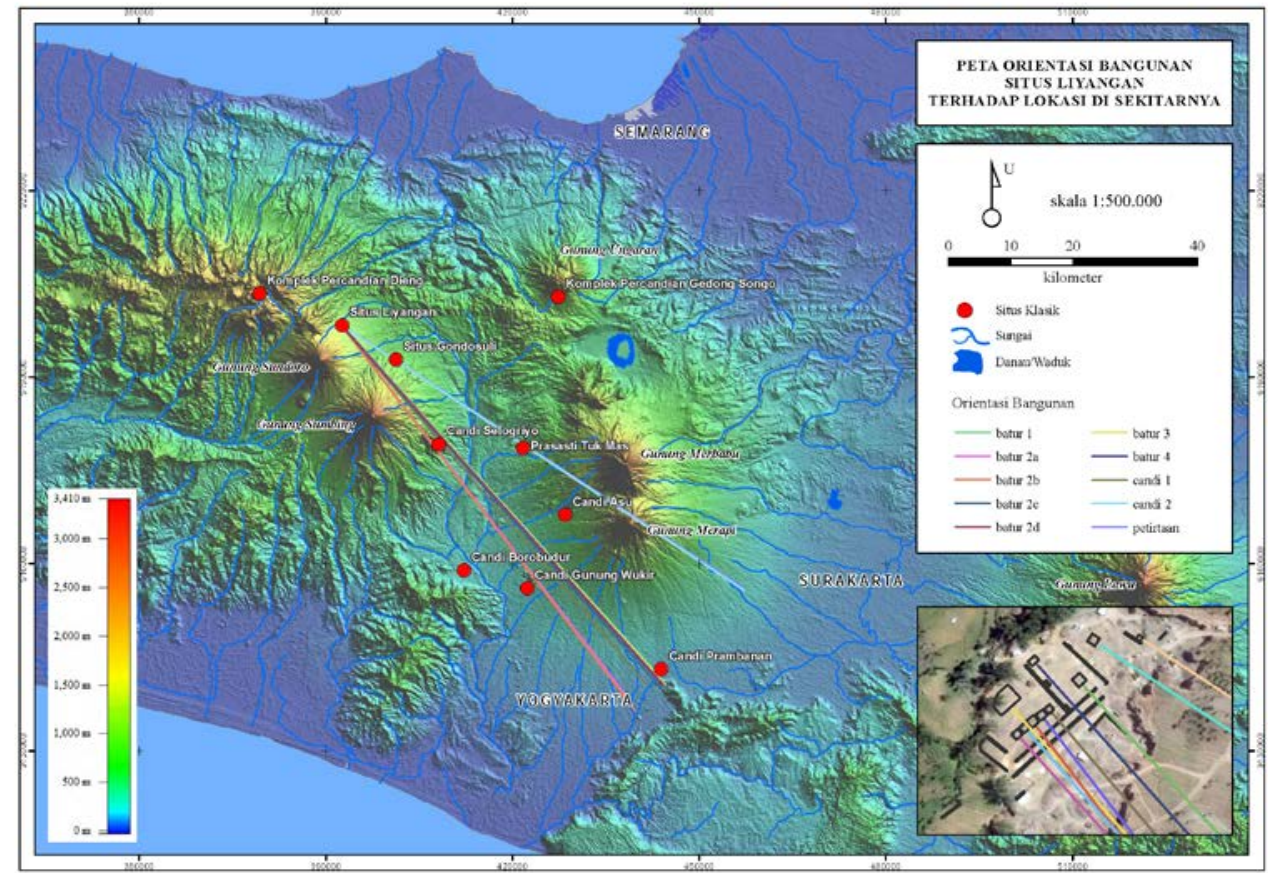

Gambar 6. Bentang garis lurus orientasi sepuluh struktur batu di Situs Liyangan yang mengarah ke Gunung Merapi, Gunung Wukir, dan Candi Prambanan (Loro Jonggrang)

(Sumber: Tim Penelitian UGM 2015)

mengarah ke Gunung Wukir atau Bukit Ratu Baka di selatan Prambanan (lihat Gambar 6).

Lalu, apakah arah orientasi ini hanya merupakan faktor kebetulan atau kesengajaan yang secara sadar dirancang oleh para pendirinya? Menurut tafsir tim peneliti, orientasi struktur-struktur itu memang telah ditentukan dengan kesadaran yang tinggi. Orientasi itu dapat dipahami sebagai lanskap spiritual pendiri dan penghuni permukiman kuno Liyangan untuk menghormati para leluhur. Sudah menjadi pengetahuan yang luas, Gunung Merapi selalu menjadi acuan penting sebagai lanskap budaya asosiatif (associative landscape) pada Mataram Hindu, bahkan berlanjut sampai Mataram Islam. Sudah disebutkan, sejumlah ahli meyakini daerah Sleman dan lereng barat daya gunung ini pernah menjadi pusat kekuasaan Mataram Hindu yang terawal. Bahkan, Slamet Muljana (2006) secara lebih khusus menulis bahwa daerah Rejodani di lereng Merapi, di utara Kota Yogyakarta, adalah pusat Kerajaan Mataram Hindu terawal. Bahkan, dapat dikatakan orientasi Candi Borobudur pun ternyata ke arah Gunung Merapi (Tanudirjo, 2011, hlm. 100). Dalam naskah-naskah kuno dari Lereng MerapiMerbabu (sekitar abad ke-16), Gunung Merapi disebut sebagai "mandaragni" (Setyawati, 1995). Sebutan ini memang seakan merujuk kepada Dewa Agni sebagai Dewa Lokapala penguasa Tenggara, tetapi hal ini hanya kebetulan saja. Alasannya, istilah itu tentu digunakan secara umum di Mataram tidak berhubungan dengan arah lokasi tertentu, sehingga mandaragni tidak merujuk 
pada Dewa Agni sebagai Dewa Lokapala di arah tenggara. Dalam kasus Gunungapi Merapi ini rujukan pada agni dalam makna umum 'api". Karena itu, mungkin sekali dalam lanskap spiritual Situs Liyangan ke arah Gunungapi Merapi didasari oleh persepsi mereka yang menganggap gunung tersebut sebagai asal-usul leluhur raja-raja Mataram Hindu (Tanudirjo, 2011, hlm. 100).

Tafsiran ini diperkuat juga dengan orientasi struktur lainnya di Situs Liyangan. Orientasi Batur 2a dan 2b ke arah Gunung Wukir atau juga Ratu Baka dapat dibaca dengan tafsiran yang sama. Seperti diketahui Gunung Wukir dikenal sebagai tempat pendirian lingga (candi) oleh Ratu Sanjaya, raja pertama dan pendiri Mataram Hindu sebagaimana disebut dalam prasasti Canggal yang ditemukan di tempat ini. Sementara itu, Ratu Baka juga menjadi rujukan sebagai salah satu pusat orientasi bangunan suci (Tanudirjo, 2011).

Orientasi struktur-struktur batu di Situs Liyangan yang mengarah Candi Prambanan diduga muncul pada periode kemudian, ketika permukiman kuno ini digunakan lagi oleh masyarakat masa tersebut sebelum mengalami bencana kedua. Dapat ditafsirkan, orientasi ini juga diarahkan ke tanah asal leluhur mengingat pendirian Candi Loro Jonggrang yang monumental itu tentu dianggap sebagai penanda penting sejarah Mataram Hindu. Lagipula, jika penafsiran Casparis bahwa pendiri Candi Loro Jonggrang adalah Rakai Pikatan yang disebutkan dalam prasasti Siwagrha adalah benar, maka menjadi suatu kewajaran apabila candi ini menjadi orientasi penduduk permukiman kuno Liyangan. Sudah disebutkan di bagian terdahulu, Rakai Pikatan adalah raja Mataram yang mungkin sekali berkuasa dari kawasan Temanggung. Perubahan orientasi ini juga menunjukkan telah terjadi pergeseran antara orientasi pada fenomena alam (Gunungapi Merapi) menjadi fenomena artifisial (Candi Loro Jonggrang). Pergeseran ini merupakan suatu gejala yang menarik untuk dikaji lebih mendalam.

Meskipun lanskap spiritual Situs Liyangan diarahkan kepada tempat "asal leluhur" sebagaimana dipersepsi para pendiri permukiman kuno tersebut. Namun, tidak dengan sendirinya dapat disimpulkan fenomena itu sebagai pemujaan leluhur atau nenek moyang. Di sini, lanskap spiritual itu semestinya lebih dilihat secara lebih kritis, dan mungkin pragmatis, sebagai upaya menyerap energi yang dianggap ada pada lokasi-lokasi tertentu. Sebagaimana dinyatakan oleh Allerton (2009, hlm. 4), lanskap spiritual adalah cara manusia membayangkan adanya tempat-tempat tertentu di dunia nyata yang dinilai mengandung energi dan kekuatan tertentu, serta wujud dari sikap manusia dalam menghadapi misteri atau "ketidakjelasan" tentang apa yang ada dibalik itu semua. Umumnya dipahami, energi atau kekuatan itu hanya nyata jika di baliknya ada mahlukmahluk yang memiliki kekuatan. Dalam konteks ini, kedudukan dan kekuatan leluhur menjadi salah yang dibayangkan sangat berpengaruh. Seperti dinyatakan Christie (1999), komunitas suatu wanua umumnya mengenal stratifikasi sosial berdasarkan pada hak-hak tanah yang diperoleh dari leluhur mereka. Nenek moyang dianggap sebagai sumber hidup, kesuburan, dan kekuatan. Karena itu, para leluhur lalu didewakan serta dipuja dengan menggunakan watu kulumpang (lumpang batu yang sakral) atau candi. Dengan demikian, pengarahan kiblat struktur batu di Situs Liyangan ke arah situs-situs asal usul leluhur atau disebut "bhumi kamulan" jelas merupakan ekspresi keinginan para penghuni permukiman kuno itu untuk menyerap energi atau kekuatan yang ada di tempat-tempat itu 
agar mereka dapat memperoleh perlindungan, penguatan, legitimasi, dan penghidupan yang lebih baik. Untuk memastikan itu, benda atau tempat yang dianggap memiliki kekuatan atau energi khusus itu layak dihormati, dipuja dan diupacarai (Allerton, 2009, hlm. 5).

\section{KESIMPULAN}

Dari hasil penelitian ini dapat diketahui hubungan yang cukup erat antara penghuni permukiman kuno di Situs Liyangan dengan para leluhur dan penguasa Mataram Hindu. Hal itu ditunjukkan dari kiblat atau orientasi sejumlah struktur batu di Situs Liyangan yang diarahkan ke tempat-tempat yang dianggap menjadi asal-usul leluhur mereka. Latar pikir lanskap spiritual penghuni permukiman kuno Liyangan ini tidak dapat disamakan dengan konsep pemujaan leluhur atau nenek moyang yang selama ini dipahami. Pemujaan leluhur lebih diarahkan pada sosok leluhur itu sendiri dan seringkali menjadi sumber kultus pribadi terhadap seseorang. Lanskap spiritual lebih merupakan ekspresi keinginan untuk menyerap energi atau kekuatan dari tempat-tempat yang diyakini memiliki energi khusus, dalam hal ini adalah tempat asal leluhur atau "bhumi kamulan". Dengan demikian, para penghuni Liyangan purba tidak saja dapat mengambil keuntungan dari energi tersebut, tetapi dapat melanggengkan kekuatan leluhur (ancestry) yang diyakininya. Kerangka pikir yang biasa digunakan dalam kajian Arkeologi Lanskap itu kiranya dapat memberikan kerangka tafsir yang cukup memadai tentang latarbelakang kiblat sejumlah struktur batu di Situs Liyangan mengarah ke tenggara, dan secara khusus ke tempat-tempat yang dianggap sebagai tempat asal leluhur mereka.

\section{UCAPAN TERIMA KASIH}

Penelitian Situs Liyangan didanai oleh Fakultas Ilmu Budaya Universitas Gadjah Mada. Selama penelitian kami dibantu oleh asisten peneliti Anindya, Henky, dan Linda Rooseline dari Departemen Arkeologi Fakultas Ilmu Budaya UGM. Peralatan total station disediakan oleh Departemen Arkeologi FIB UGM. Untuk itu, diucapkan terima kasih. 


\section{DAFTAR PUSTAKA}

Abbas. N. (ed.). (2014). Liangan: Mozaik Peradaban Mataram Kuno di Lereng Sindoro. Yogyakarta: Balai Arkeologi Yogyakarta.

Allerton, C. (2009). Introduction: Spiritual Landscapes of Southeast Asia. Anthropological Forum, 19 (3), 235-251.

Andrianto, A. (2014). Biji Jagung Purba Ditemukan di Situs Liyangan, Tempo Online 24 Oktober 2014. (www. nasionaltempo.co)

Atmadi, P., (1977). Bunga Rampai Arsitektur dan Pola Kota Keraton Majapahit, dalam S. Kartodirdjo, dkk. 700 Tahun Majapahit (1293 - 1993). (h.117 - 130). Jawa Timur: Dinas Pariwisata Daerah Provinsi Jawa Timur.

Balai Arkeologi Yogyakarta. (2012). Laporan Penelitian Arkeologi Situs Liyangan, Temanggung, Jawa Tengah, Tahun 2012. Yogyakarta, Indonesia: Tim Penelitian.

Balai Arkeologi Yogyakarta. (2013). Laporan Penelitian Arkeologi Situs Liyangan, Temanggung, Jawa Tengah, Tahun 2013 Yogyakarta, Indonesia: Tim Penelitian.

Balai Arkeologi Yogyakarta. (2014). Laporan Penelitian Arkeologi Permukiman Masa Mataram Kuna Situs Liyangan, Temanggung, Jawa Tengah. Yogyakarta, Indonesia: Tim Penelitian.

Casparis, J.G. de. (1950). Prasasti Indonesia I. A.C. Nix and Co, Bandung.

Casparis, J.G. de. (1956). Prasasti Indonesia II. Masa Baru Bandung.

Christie, J.W. (1990). Wanua, Thani, Paraduwan: the Disintegrating Village in Early Java?, Manuscript. 1 May 1990. Centre for Southeast Asian Studies, University of Hull, England.

Eriawati. Y. (2014). Keramik Cina Dinasti Tang Abad IX Masehi dari Situs Liangan, Temanggung, Jawa Tengah, dalam Abbas. N. (ed.), Liangan: Mozaik Peradaban Mataram Kuno di Lereng Sindoro (hlm. 215-265). Yogyakarta: Balai Arkeologi Yogyakarta.

Grattan, J and R. Torrence. (2007). Beyond Gloom and Doom: The long term Consequences of Volcanic Disaster, dalam J. Grattan and R. Torrence (eds), Living Under The Shadow: the Cultural Impacts of Volcanic Eruption (hlm 1-18). Left Coast Press.

Istari, T.M. Rita. (2014). Pendataan TemuanLepas Tinggalan Arkeologis Situs Liangan dan Sekitarnya. Dalam Abbas (ed.) Liangan: Mozaik Peradaban Mataram Kuno di Lereng Sindoro (hlm. 201-214). Yogyakarta: Balai Arkeologi Yogyakarta 
Knapp, A.B. and W. Ashmore. (1999). Archaeological Landscapes: Constructed, Conceptualised, Ideational. Dalam Archaeologies of Landscapes: Contemporary Perspectives (eds) W. Ashmore and A.B. Knapp (hlm. 1-30). Blackwell, Oxford.

Layton, R. and P.J. Ucko. (1999). Introduction: gazing on the landscape and encountering the environment, dalam Layton, R. and P.J. Ucko (eds.) The Archaeology and Anthropology of Landscape Shaping Your Landscape (hlm. 120). Routledge.

Lohuizen-de Leeuw, J.E. van. (1955). The Dikpalakas in Ancient Java, Bijdragen tot de Taal-, Land-, en Volkenkunde 111, 356 - 384.

Mochtar, A.S. (2014). Wanua i Rukam, Nama Asli Situs Liangan ? Dalam Abbas (ed.) Liangan: Mozaik Peradaban Mataram Kuno di Lereng Sindoro (hlm. 149 163). Yogyakarta: Balai Arkeologi Yogyakarta

Muljana, S. (2006). Sriwijaya. Yogyakarta: LKis.

Nastiti, T.S. (1982). Tiga Prasasti Masa Balitung. Jakarta: Puslitarkenas.

Noerwidi, S. (2014). Sisa Rangka Manusia dari Situs Permukiman Mataram Kuna - Liangan, temanggung, Jawa Tengah. Dalam Abbas (ed.) Liangan: Mozaik Peradaban Mataram Kuno di Lereng Sindoro (hlm. 293 - 320). Yogyakarta: Balai Arkeologi Yogyakarta

Nurnusanto, I. (2014). Catatan Geologis Geologi Situs Candi Liangan, dalam Abbas (ed.) Liangan: Mozaik Peradaban Mataram Kuno di Lereng Sindoro (hlm. 117 - 122). Yogyakarta: Balai Arkeologi Yogyakarta.

Putra, R., I Nurdin, H. Pamungkas, dan S. Dwiyono. (2013). Penyelidikan Stratigrafi untuk Mengetahui Sejarah Geologi Daerah Candi Liangan, Purbosari, Temanggung, Jawa Tengah. Buletin Berkala Merapi Vol 13 No. 3 Desember 2013, 42 - 52.

Resiyani, W. (2010). Toponim Masa Kini Berasal dari Sumber Prasasti abad IX - X Masehi yang ditemukan di Kabupaten Temanggung, Jawa Tengah. (Skripsi). Sarjana Jurusan Arkeologi Universitas Gadjah Mada, Yogyakarta.

Riyanto, S. (2014a). Prolog. Dalam Abbas (ed.) Liangan: Mozaik Peradaban Mataram Kuno di Lereng Sindoro (hlm. 1 - 29). Yogyakarta: Balai Arkeologi Yogyakarta.

Riyanto, S. (2014b). Menggali Peradaban Mataram Kuno di Liangan Tahap Demi Tahap. Abbas (ed.) Liangan: Mozaik Peradaban Mataram Kuno di Lereng Sindoro (hlm. 31 - 115). Yogyakarta: Balai Arkeologi Yogyakarta.

Setyawati, K. (1995). Naskah-naskah Merapi-Merbabu, Koleksi Perpustakaan Nasional Indonesia (Tinjauan Awal). Humaniora I, 1995, 35 - 42. 
Sheet, P. (2007). People and Volcanoes in the Zapotitan Valley, El Salvador, dalam J. Grattan and R. Torrence (eds), Living Under The Shadow : the Cultural Impacts of Volcanic Eruption (hlm. 67-89). Left Coast Press

Soekmono. (1977). Candi Fungsi dan Pengertiannya. (Disertasi). Jakarta: UI.

Sukhyar et.als. (1992). Peta Geologi Gunungapi Sundoro, Jawa Tengah. Direktorat Geologi Bandung, 1992.

Sukhyar R, Sumartadipura N S, dan Erfan R D, (1992). Geologic map of Sundoro volcano, Central Java. Volcano Survey Indonesia. Peta Geologi Sundaro skala1:50,000.

Tacon, P.S. (2011). "Landscape: Politics and Perspectives". Antiquity, April, 2011 diperoleh dari http://findarticles.com/p/articles/mi_hb3284/is_n260_ v68/ain28647571/

Tanudirjo, D.A. (2011). Dampak Erupsi Gunung Merapi Terhadap Candi Borobudur, dalam Sutopo, M (ed.), Menyelamatkan Candi Borobudur dari Erupsi Merapi (hlm. 99-116). Magelang: Balai Konservasi Peninggalan Borobudur.

Thomas, J. (2001). Archaeologies of Places and Landscapes, dalam I. Hodder (ed), Archaeological Theory Today (hlm. 165-186). Polity Press.

Tuan, Fi Yu, (1977). Space and Place, The Perspective of Experience. Minnesota University Press. Mineapolis.

UNESCO. (2012). Operational Guidelines for the Implementation of the World Heritage Convention. World Heritage Centre Paris.

Wunderman, R (ed.), (2013). Global Volcanism Program: Report on Sundoro (Indonesia), Bulletin of the Global Volcanism Network, 38: 8. http://dx.doi.org/10.5479/si.GVP.BGVN201308-263210

Wunderman, R (ed.). (2013). Report on Sundoro (Indonesia) Global Volcanism Program 2013. Bulletin of the Global Volcanism Network, 38. (http://dx.doi.org/10.5479/si.GVP.BGVN201308-263210)

Yuwono, J.S.E. (2013). Kajian Spasio-Temporal Lereng Utara Gunung Sindoro dalam Hubungan Kewilayahan dengan Situs Liyangan, Temanggung, Jawa Tengah. Laporan Penelitian Jurusan Arkeologi FIB UGM (tidak diterbitkan). 